\title{
MATERIALISM NEW AND OLD
}

Charles T. WOLFE

Ghent University, Belgica. charles.wolfe@ugent.be

\section{MATERIALISMO NUEVO Y ANTIGUO}

Resumen: El nuevo materialismo no es un conjunto claro de tesis, ni una escuela firmemente unificada de pensamiento. Cruza discursos y compromisos teóricos, pero, como su nombre indica, parece oponerse consistentemente al materialismo "nuevo" a una forma más antigua, o quizás a varias formas más antiguas de esta doctrina. Estos últimos se asocian típicamente con puntos de vista "mecanicistas", con "reduccionismo", con la negación de la vida, la agencia, la encarnación, el significado, el valor ... ¿Qué sucede cuando un historiador del materialismo se enfrenta a tales afirmaciones? En lo que sigue, reflexiono sobre los problemas históricos que afectan a tales posicionamientos teóricos. No es que no haya necesidad de distinguir las formas pasivas de las formas activas del materialismo, ni de destacar un enfoque en la vida orgánica. Pero que una distinción entre "nuevo y antiguo" podría no ser la manera de capturar características históricas e históricas cruciales.

Abstract: New materialism is not a clear-cut set of theses, or a firmly unified school of thought. It crosses discourses and theoretical commitments, but, as its name indicates, seems consistently to oppose 'new' materialism to an older form, or perhaps several older forms of this doctrine. The latter are typically associated with 'mechanistic' standpoints, with 'reductionism', with the denial of life, agency, embodiment, meaning, value ... What happens when a historian of materialism confronts such claims? In what follows, I reflect on the historical problems which affect such theoretical positionings. It is not that there is no need to distinguish passive from active forms of materialism, or single out a focus on organic life. But that a distinction between 'new and old' might not be the way to capture such crucial theoretical and historical features.

Palabras clave: Materialismo, Teoria Histórica, Analisis, Cambio, Comparación Materialism, Historical Theory, Analysis, Change, Comparison 
New materialism ${ }^{\mathbf{1}}$ is not a clear-cut set of theses, or a firmly unified school of thought. One distinctive feature it displays consistently is a shift in focus within feminism towards 'naturalistic' themes - these can include biology, embodiment understood other than in a strictly constructivist sense, and even, most surprisingly, matter itself, on a kind of ontological plane of immanence. With the focus on matter itself (whether as a kind of technological residue covering the earth, or as fundamental physics) comes a certain oppositional move, not always explicit, but recurrent: the opposition between an older vision of a merely passive matter, towards which the rich qualitative texture of reality is reduced, and a newer vision of a dynamic matter. Old materialism (hereafter OM), on this view, was caught in between a physics-obsession, a mechanistic vision of the world (never very well defined, as it happens), and a kind of reductionism which would translate any higher-level phenomenon or entity (feelings, the body, consciousness and so on) into any combination of the aforementioned trinkets of physicalism and/or mechanics. Thus translated, matter could not be ensouled, alive or otherwise dynamic; it could only be characterized by the basic properties of size, shape and motion. Contrasting with this completely formalized landscape, in New Materialism (hereafter NM), "Matter is not immutable or passive" (Barad 2003, 821); "New materialism has for some time moved towards an understanding of matter as a complex open system subject to emergent properties" (Hird 2004, 226); "new materialist ontologies are abandoning the terminology of matter as an inert substance subject to predictable causal forces" (Coole and Frost 2010, 9).

What happens when a historian of materialism confronts such claims? One problem is that NM oscillates between strictly theoretical and political claims (about the Now) and historical claims (about Hobbes, or Descartes, or Newton, not to mention Nietzsche, Bergson and others). ${ }^{2}$ This is of course its privilege and it would be crude or petulant at best to deny a theoretical project the liberty to construct its own history. But as to the historical claims proper - by which I do not mean strictly factual claims of the sort, 'La Marquise sortit à cinq heures' but rather claims about the internal logic of the systems of past thinkers like Descartes or indeed self-proclaimed materialists such as La Mettrie - one is entitled to engage in debate, definitely. I will seek to engage with one particular set of claims above all: the opposition between a passive and static vision of matter (which NM attributes to OM) and an active and dynamic vision of matter (which NM claims for itself).

The distinction between passive and active forms of materialism is not per se chronological or 'diachronic', as it exists in clearly synchronic form: that is, there was no need of Marx, Nietzsche, Freud, or phenomenology (all of which are variously credited by new materialists, giving an oddly ' 1973 ' flavour to the whole thing) for materialism to include tensions between the vision of an inert, dead, static, passive matter and some form of animate(d) matter. As I have emphasized elsewhere, John Toland's insistence on activity as the "essen-

1 Elements of this paper have been presented in Ghent (Literary Studies Group, December 2015), Princeton (Institute for the Humanities, February 2016) and, via Skype, in Cordoba (Neomaterialismo conference, September 2016). Thanks to various participants for their suggestions.

2 Spinoza is surprisingly absent from this conceptual landscape, as far as I could tell, despite (a) the various discussions since the early 1970s dealing with his relation to possible projects of materialism (surveyed from a strictly internal-philosophical standpoint in Korichi 2000, and from an explicitly Marxist, although not Negrian standpoint in Tosel 1994) and (b) more recent feminist interpretations of his thought (Gatens ed. 2009); in the latter collection, Heidi Morrison Ravven's essay notes that feminism still relies on a notion of free will that has Augustinian and Kantian overtones, whereas Spinoza's critique of free will has dispensed with this. Frost may be noting something like this when she writes, "In turning to culture to evade the determinism implicitly associated with the biological body, feminists recapitulate the modern fantasy of freedom, autonomy, and selfdetermination that they have otherwise so carefully dismantled" (Frost 2011, 77). 
ce" of matter (Toland 1704), and later, Diderot's promotion of sensibility as a "universal" or "essential" property of matter (he uses both terms) are characteristic moments of first, an active-matter materialism and subsequently, a vital materialism (Wolfe forthcoming). (One could, counterfactually but without too much effort, imagine new-materialist reflections on a 'good' vision of active matter, in Francis Glisson, Margaret Cavendish or Diderot, versus a 'bad' vision of mechanistically specified passive matter, in Hobbes or d'Holbach. But such an opposition, reminiscent of works such as Carolyn Merchant's Death of Nature, yields a best a neo-paganism, which is an odd point of arrival for materialism, but one which would be welcomed by those for whom the "new materialist ontology" focuses on the "vibrant, constitutive, aleatory and even immaterial indices that characterize the new senses of materiality and materialization,"3 which is how Jane Bennett presents her Vibrant Matter.) So my first general point is that the passive-active opposition is an impoverished and out of date vision of early modernity (or, which amounts to much the same in the end, that such an opposition was already active then).

As such, calls for a 'new materialism' which would do justice to the reality of embodiment; to the historicity of the body; perhaps to a degree of agency implied in the possibility of self-construction - a kind of cyborg materialism, as it were - make sense, if juxtaposed to this construct of a mechanistic materialism, where the body is understood as being like a "statue or machine made of earth," in Descartes' celebrated phrase from L'Homme (AT XI, 120), or as a system of pulleys, funnels and sieves. New-materialist calls to attend to materiality, experience and self-construction seem convincing when contrasted with this 'Cimmerian' vision of an early modern context in which, as Jonathan Sawday put it, "As a machine, the body became objectified; a focus of intense curiosity, but entirely divorced from the world of the speaking and thinking subject." 4 And indeed they too take Descartes' passive matter, and his conception of the body as "unthinking," as a target - neglecting the thorny question of the union, and of Elizabeth's influence on his thinking as regards the passions, later in life. But they may be based on rather patchy scholarship, in an area that at least needs revisiting.

This vision of impoverished mechanism often took the form, in Marxist discourse, of the concept of mechanistic materialism (again, an oppositional construct designed to valorize what it was not: either a 'non-mechanistic' materialism, as in Marx and Engels, as we shall see below, or more often, some form of spiritualism or at least insistence on the autonomy of the person, consciousness, the soul, free action, and so forth, which were always opposed to the 'blind necessity' of clocks and other mechanical devices). ${ }^{6}$ But if we examine the reality of early modern materialism a bit more closely, the concept of mechanistic materialism falls apart, as does the pertinence of a new materialism opposed to this purportedly static and mechanistic older model, at least as regards its attempt to articulate an opposition between 'old' and 'new', passive and active, inert and dynamic (recall the claim that NM ontologies are abandoning any notion of matter as inert and causally determined, in favour of chaos, dynamism and emergence; here, a dose of De rerum natura might be in order). A case in point would be the following statement by Friedrich Engels, well known to historians of materialism but perhaps less known to the New Materialists (who might discover an unknown ancestor!):

3 Coole and Frost 2010, 14-15; emphasis mine

4 Sawday 1995, 29.

5 Frost 2011, 72.

6 As a side-note, there is a rich history and ideological Begriffsgeschichte to be told of this concept, as it moves through the Christian anti-materialism of the Cambridge Platonists, to Marxism-Leninism, pre-Althusserian existential humanist Marxism (e.g. Sartre's well-known "Materialism and Revolution," Sartre 1946) and onto certain strains of embodied phenomenology and enactivist cognitive science (building on Merleau-Ponty 1963, including Thompson 2007), at times intersecting or overlapping with NM. 
The materialism of the past century was predominantly mechanistic, because at that time ... only the science of mechanics ... had reached any sort of completion... . For the materialists of the eighteenth century, man was a machine. This exclusive application of the standards of mechanics to processes of a chemical and organic nature ...constitutes the specific (and at that time, inevitable) limitation of classical French materialism. ${ }^{7}$

It seems as if Engels is the first New Materialist; or that his mixture of normative language and historical claims closely prefigures the supposedly 'new' New Materialist moment - and not in a good way, for his statement is multiply problematic. We are faced with two interpretive problems here: the concept of mechanistic materialism, and more broadly, the contents of 'new' versus 'old' (including purportedly mechanistic) materialism. For nothing prevents the contemporary theorist concerned with materiality, selfhood and the body from calling their position 'new materialism', as I said above with respect to the freedom enjoyed by the theorist; but the historiographic and indeed philosophical claims contained therein may turn out to be fragile indeed ....

In what sense does the notion of mechanistic materialism, including Engels' historical proclamation, fall apart? At least three aspects should be distinguished.

First of all, writers using the notion often curiously neglect the major metaphysical gap between mechanism, as represented for instance by Descartes, Galileo and Boyle, and materialism. It is disconcerting to read New Materialists equating Cartesian and Newtonian concepts of matter, sometimes even speaking of "The Cartesian-Newtonian understanding of matter" as "domination of Nature" or "older Cartesian-Newtonian conceptions of matter and correspondingly Promethean ideas of human mastery over nature" (Coole and Frost 2010, 8, 17), a project Newton would not have endorsed. Philosophically speaking, the majority of early modern mechanists were either substance dualists or agnostic concerning the nature of a foundational 'substance' such as matter. This seems both rather well known (although confusion persists) and unproblematic, so I will not dwell on it further.

Second, those who wield the concept of mechanistic materialism neglect - in this participating in a broader tendency towards intellectual blindness or at least narrow-mindedness - the presence of a strong, explicit and diverse concern with embodiment in various early modern materialists (as discussed in Wolfe 2012 and Wolfe 2016, chapter 4). This includes the common tendency to take works such as La Mettrie's L'Homme-Machine literally: despite the (provocative) title of his work, La Mettrie never reduces the properties of the living body to the properties of inanimate matter, or those of 'machines' - which machines? and after all, weren't Enlightenment automata all about a fascination with life? (Riskin 2003) - or the organic to the inorganic. L'Homme-Machine is indeed a bold piece of reductionist argumentation, but as I have stressed elsewhere, the reduction proposed therein is a soulbody reduction.

I shall only mention the third of Engels' mistaken claims: the assumption that chemistry emerged suddenly in the nineteenth century (or at least with Lavoisier); scholars of the eighteenth century, including of materialism, are actually quite familiar with what one might term the chemical obsession in matter theory and materialism; the point obviously not being to claim scientific 'truth' for this episode, but to call attention to the way in which material entities were very much understood in the new and evolving chemical terms (and this intersects explicitly with the emergence of Enlightenment vitalism as well, which is another part of the story).

Rather than 'old' and 'new', we should distinguish, then, between materialisms based on passive matter and on active matter, where the latter focus on activity includes notions of dynamism, self-transformation, plasticity, and so on. And the latter set of properties is precisely what the 'new materialist' theorist claims is - new, or at least 'new' in the sense that

7 Engels 1888, in Marx \& Engels 1982, 278. 
Bergson or Whitehead will be considered familiar while Anthony Collins, Denis Diderot or Joseph Priestley will not (together with the occasional erroneous inclusion of Descartes in the older materialism). The distinction between passive and active forms of materialism is not per se chronological or 'diachronic', as I noted at the outset: that is, there was no need of the hermeneutics of suspicion, of Freudian energetics or of the phenomenology of the corps propre for materialism to include tensions between the vision of an inert, dead, static, passive matter and, e.g., a vital matter concept (whether more 'animistic' like Glisson or Cavendish, or more reduction-friendly as in Toland, La Mettrie and Diderot).

One problem then in the opposition between NM and OM is the existence of an embodied materialism in the early modern and Enlightenment periods. But it is not that NM exists in a kind of prefiguration some centuries earlier: just because Lady Margaret Cavendish thought that "the soul of nature must be corporeal, as well as the body..."; that it was just as probable that "God did give matter a self-moving power to her self, as to have made another creature to govern her? For nature is not a babe, or child, to need such a spiritual nurse, to teach her to go, or to move ..."; that "if Nature were not self-knowing, self-living and also perceptive, she would run into confusion," ${ }^{\circ}$ it does not make her a New Materialist. Nor, just because Toland or Diderot have active matter concepts, does it make them New Materialists. That the 'newness' implicit in the idea of NM might be more of a re-packaging affair than expected, does not make OM and NM the same. (An interesting sub-issue I shall not explore here concerns the gray area between OM and NM: Democritus and Hobbes definitely belong to the former while Rosi Braidotti and Elizabeth Grosz belong to the latter, but what about Bergson or Whitehead? They are not really materialists but could be coopted into the virtual-friendly NM. Feuerbach's anthropological focus puts him in that in-between area as well. What about Wilfrid Sellars and his father, Roy Wood Sellars? They are twentieth-century materialists who are anti-reductionist, anti-mechanistic, and emergentist ...)

Active, vital and/or embodied materialism in the long early modern period take different forms. While La Mettrie and Diderot reject 'soul' and seek to build up complexity from a 'bottom-up' standpoint (albeit one in which the minimal particles of matter possess life), someone like Cavendish (who often gets called a materialist today, although this seems vague to me) is attributing higher-level properties such as 'soul' to matter itself (and getting embroiled in rather circular definitions of matter as either inanimate, sensitive or rational, the latter two being both species of animate matter). The former, reduction-friendly vital materialist, could not follow NM in its occasional dalliances with phenomenology and/ or enactivism, as in "the mind does not use the body, but fulfills itself through it while at the same time transferring the body outside of physical space" (Merleau-Ponty), ${ }^{9}$ a form of dualism which traces back to the Husserlian distinction between Körper, 'body' in the sense of one body among others in a vast mechanistic universe of bodies, and Leib, 'flesh' in the sense of a subjectivity which is the locus of experience, or "Life is not physical in the standard materialist sense of purely external structure and function. Life realizes a kind of interiority, the interiority of selfhood and sense-making. We accordingly need an expanded notion of the physical to account for the organism or living being" (Thompson 2007, 238). In fact, this "expanded notion of the physical" has always been present; it is rather the impoverished picture of "standard materialism" (reminiscent of Engels again) that needs to be revised. The latter, reduction-hostile vital materialist (like Cavendish and perhaps Schiller later on), however lacks any interest in historicity or anti-essentialism.

However, even if the vision of OM as dependent on a passive matter concept misses numerous features of early modern materialism, so that the twin objections voiced by Engels

8 Cavendish 1666, "Observations upon the opinions of some ancient philosophers," I, 5 (this treatise is independently paginated); Cavendish 1664, ch. II, 6; Cavendish 1668, ch. VIII, 7.

9 Merleau-Ponty 1963, 208-209 (trans. modified). 
and NM are not immune to the consequences of a closer examination of vital materialism, this does not mean that all of the features of new materialism are simply 'there' in the early modern period. For instance, subjectivity. ${ }^{10}$ Not because it was such a conceptual improvement to insist on first-personness, anti-naturalism, like Husserl's rather Fichtean pronouncements such as, "it is only when the mind ceases to naïvely turn towards the outside and returns to itself, in order to dwell in itself, purely in itself, that it can be self-sufficient." 11 It is surprising for 'critical' theorists to continue endorsing normative distinctions between the world of privacy, interiority, selfhood, value and a merely spatial, science-friendly externalist presentation of the world, including the ideologically rather crude attack on "standard materialism" in enactivist argumentation, as cited above.

Rather than this kind of crypto-dualistic intuitive appeals to a more authentic inner world versus a dehumanized world of externality, concerns with materiality in recent feminist discourse are certainly not so dualist. This may have been true in some cases, but is not e.g. of Karen Barad, whose work is perhaps the major instance of feminist science studies embracing naturalism (Barad 2003). Barad is unique in seeking to connect science studies to a feminist ontology, in which subject and object are "intra-actively constituted," as she says, within specific practices. Barad's "agential realism" holds that we are, both metaphysically and ethically, "accountable" to the material. However, this accountability "is not about representations of an independent reality, but about the real consequences, interventions, creative possibilities, and responsibilities of intra-acting within the world" (Barad 1996, 188). This is a form of NM because she emphasizes, again with a stress on "intra-action," that materiality is agential reality (Barad 1998, 109). ${ }^{12}$

In addition, Barad maintains that "the body's materiality - for example, its anatomy and physiology ... actively matter to the processes of materialization" (Barad 2003, 809), and the better we understand this, the more we can - agentially - connect body and power. Fans of Spinoza would feel in familiar territory, with the connection between body and power, and the idea that increased knowledge of the body is increased power of acting; in Deleuze's terms, "One recalls Plato saying that materialists, if at all intelligent, should speak of power rather than of bodies. But it is true, conversely, that intelligent dynamists must first speak of bodies, in order to 'think' power" (Deleuze 1990, 257).

A difference that does endure, in my view, between vital materialism and new materialist talk of 'materiality', is that the latter is primarily defined in terms of (and oriented towards) issues of agency, self-construction and historicity, notably with regards to gender (even if the extent to which narratives of 'construction' and anti-essentialism are univocal or in agreement, including in a specifically feminist context, is at best unclear: see the commentary in Ahmed 2008). In one statement of the field,

in many respects, a scholarly and theoretical focus on the body's materiality is nothing new: for several decades, feminists have denaturalized both embodiment and material objects, analyzing and specifying the manifold discursive practices through which bodies and matter are constituted as intelligible. The focus of such work has been on elucidating the processes through which norms and power relations are incorporated as forms of subjectivity or materialized in institutions, cultural practice, and facts (Frost 2011, 70).

Or, in Barad's phrase, for new materialists, "matter is always already an ongoing historicity" (Barad 2003, 821); she has added more recently that "Materiality itself is always al-

10 I offer some suggestions for an early modern materialist theory of self (although not subjectivity or interiority), with reference to Diderot, in Wolfe 2015.

11 Husserl 1976, chapter II, 95.

12 One can see this as a sort of Cartwrightian reminder that we need not be subservient to a Vienna Circle-style picture of a nomological nature, while nevertheless not reacting to this by being anti-naturalists, since we should recognize the constitutive interaction between experiment, apparatus, subject, etc. (which was also Ian Hacking's point). 
ready a desiring dynamism, a reiterative reconfiguring, energized and energizing, enlivened and enlivening" (interview in Dolphijn \& van der Tuin 2012, 59).

Even if authors like Barad have sought, in the name of a 'relational ontology', to blur the boundaries between this less naturalistic sense of materiality and the world of biological life, nevertheless, materiality has very little to do with either the biomedical analyses which vital materialists appealed to (including in speculative ways), or with their reductionist, deflationary impetus. It is, to use Frost's word above, more of a 'denaturalization'. There is no sense of either the explanatory power of reductionist explanations, or even, sensu La Mettrie, of their metaphysical courage, in the New Materialist ontophanies of 'materiality, vitality, relationality, self-creativity, productivity, unpredictability', including Jane Bennett's "enchanted materialism," which ascribes agency to "inorganic phenomena such as the electricity grid, food and trash," 13 or Elizabeth Grosz' Bergsonian insistence that "Life makes matter artistic." 14 Indeed, in the focus on 'denaturalization' and 'historicity' (concepts with which twentieth century anti-naturalism, e.g. of a Heideggerian or Sartrean sort, made a lot of hay), it's not clear that our hormones, headaches, hallucination or our enhanced, articialized, cyborgized bodies are given much air time: as Kirby described (cited adversarially by Ahmed, but we can extract the quotation from its usage in her article),

I was left wondering what danger had been averted by the exclusion of biology. What does the nominative 'biological or anatomical body' actually refer to? . . . When I asked a question to this effect it was met with a certain nervous comprehension. Deciding, perhaps, that I must still be immersed in a precritical understanding of the body, the speaker dismissed me with a revealing theatrical gesture. As if to emphasize the sheer absurdity of my question she pinched herself and commented 'Well I don't mean this body'. ${ }^{15}$

Additionally, theories of materiality, including now the new materialism, even though the latter emphasizes its engagement with biology as another 'agential' source, challenge the 'essentialism' of traditional materialism, and sometimes its scientism (often with a surprisingly outdated vision of Descartes, Newton and the 'old materialists' as ideologists of the mastery and possession of nature, as noted earlier). In fact, the embodied and/or vitalistic trends in OM are neither an essentialism nor a scientism (least of all in Diderot), nor do they privilege the 'subjective', unlike theories of materiality: "The materialist trend in philosophy recognizes the existence of objective external reality, as well as its independence in relation to the knowing and perceiving subject. It acknowledges that being, the real, exists and is prior to its discovery, prior to the fact of being thought and known."16

How should the historian of materialism respond to NM, then? As noted in the beginning, one difficulty is the lack of theoretical coherence between different versions of the latter 'position'. For instance, some endorse phenomenology and enactivism (thus romances of the Subject) while others are decisively posthumanist, even at times aligned with 'objectoriented ontology'; thus Bennett, after declaring herself more of an Epicurean materialist than a Marxist or Frankfurt School kind, states: "my contention is that there is also public value in following the scent of a nonhuman, thingly power, the material agency of natural bodies and technological artifacts" (Bennett 2010, xiii) - a kind of fetishism of objects and

13 Bennett 2001 and 2010; Coole and Frost 2010, 9. Less redolent of cosmology, ontophany or 'rational metaphysics', to use a Kantian phrase, is the debate on whether feminist theory should embrace biology (and how much of it): see Davis 2009.

14 Grosz 2011, 24.

15 Kirby 1997, cit. in Ahmed 2008, 23. Of course, to the inclusion of biology one can ask, which biology? (Oyama's? Margulis's? Roughgarden's? and so on).

16 Althusser 1994, 60. The later Althusser's aleatory, Lucretian materialism seems a richer way of handling 'old/ new' concepts in materialism than NM (whether the ontophanic kind, as in Bennett, or the more historicized versions); but to be fair, some new materialists have identified Althusser as a kindred spirit: see Coole and Frost 2010, 35). 
of immanence. More soberly but also on this line, Frost speaks of "matter or the body as having a peculiar and distinctive kind of agency, one that is neither a direct nor an incidental outgrowth of human intentionality but rather one with its own impetus and trajectory" (Frost 2011, 70). With respect to the more subject-oriented versions, the contrast between $\mathrm{NM}$ and $\mathrm{OM}$ is clear, for the latter never strays far from its Epicurean-Lucretian roots as a 'thinking of the body'. With respect to the hyper-ontologized versions of NM, the contrast is not so easy to draw. I've earlier suggested that its presentation of OM as passive and mechanistic does not survive a short historical overview of some early modern and Enlightenment episodes; Engels and NM need to revise either their history or at least their oppositional claims. But there is a more systematic contrast to explore, in addition.

One clear difference between OM and NM here is that the older version has a distinctly disturbing, destabilizing character - the sense in which, as La Mettrie put it, "He who chooses man as an object of study must expect to have man as an enemy." 17 If materialism in general is indeed an ontology, and a claim about the totality of being, in the case of OM such ontologies tend to be constructed in a hostile relation to, e.g. normative moral philosophy, the immortal soul, the divine right of kings, and so forth. In contrast, NM, when it flirts with virtuality, ${ }^{18}$ immanence and flat ontology ${ }^{19}$, which one critic recently called 'curating concreteness' ${ }^{20}$ lacks this kind of opposition - a point made by several of the authors featured in the October 'New materialisms' questionnaire of this year, including Galloway and Wark.

Now, as a kind of caveat, if my claim was that OM and NM treated as ahistorical or perhaps supra-historical entities could be compared, and that the scandalous atheism and immoralism of the former made it a more admirably disturbing object than the ontophanic embrace of the "vibrancy of matter" in NM (more admirably, thus in a sense laden with ethico-political overtones), it would run into an important objection, formulated in an article that appeared this summer:

the meaning of the pretense to enlightened secularism here and now is not what it was in Europe 300+ years ago. Hence, when we talk about vital materialism-the pursuit of the secret of life--today and in the history of Western thought, we are talking about politically incommensurate rhetorical and intellectual projects" (Willey 2016, 9).

I may be guilty elsewhere of some of this elision of incommensurability (e.g. in my chapter on materialism and ethics in Wolfe 2016) but here, I am content to keep to the case of passive vs active matter and materialism, and how this polarization functions in $\mathrm{OM}$ and NM. Indeed, just as with vitalism (or with the Stalinist usage of the concept of mechanistic materialism), the political fortunes of these ideas can take us into a longer and stranger $B e$ -

17 Discours sur le bonheur, in La Mettrie, 1987, II, 269.

18 Some NM theory, not so much Braidotti as Grosz (e.g. Grosz 2011, 18), is enamored with the virtual as a spark of life.

$19 \mathrm{NM}$ often claims, in more or less explicit relation to or piggy-backing on object-oriented ontology or Latourian speculative realism, to be effecting a kind of paradigm shift "from epistemology, in all of its relation to critique, to ontology, where the being of things is valued alongside that of persons" October 155 (Winter 2016), questionnaire on new materialism, Presentation, 3. Recall that in both Latour and his metaphysical fellowtraveller Graham Harman, "apples, vaccines, subway trains, and radio towers" are taken seriously as topics of philosophy - which if they were taken individually, is not very earth-shaking, but they are taken in toto; they are not "mere images hovering before the human mind, not just crusty aggregates atop an objective stratum of real microparticles, and not sterile abstractions imposed on a pre-individual flux or becoming," but rather "autonomous forces to reckon with, unleashed in the world like leprechauns and wolves" (Harman 2009, 5-6); philosophy is not stuck "amidst the shifting fortunes of a bland human-world correlate, but in the company of all possible actants: pine trees, dogs, supersonic jets, living and dead kings, strawberries, grandmothers, propositions, and mathematical theorems" (16).

20 Bill Brown, in October Questionnaire, 13. Thanks to Brooke Holmes for sharing this material with me. 
griffsgeschichte, as I mentioned at the outset.

Again, theoretical inventivity need not be constrained by some rule-book. If one thinks 'thingly power' is liberating, perhaps it can be liberating for some. But the reason I became interested in materialism in the first case (actually while reading the Marquis de Sade as an undergraduate) was not to find out that the material was the virtual, and that Bergsonism was the deepest form of this philosophy! This late $20^{\text {th }}$-early $21^{\text {st }}$ century move to ontology is not without problems, or costs at least: on the one hand, a kind of foundationalist problem (who gets to say the Real?) and on the other hand, an immanentist problem: if everything is real, on a flat plane of ontology, boarding passes and chewing gum and chimichurri and soft power and ghosts, then what?

\section{References}

Ahmed, S. (2008). "Imaginary Prohibitions. Some Preliminary Remarks on the Founding Gestures of the 'New Materialism'," European Journal of Women's Studies, 15: 23-39.

Althusser, L. (1994). "Le courant souterrain du matérialisme de la rencontre" and 'Portrait du philosophe matérialiste." In Écrits philosophiques et politiques, vol. I, ed. F. Matheron. Paris: Stock/IMEC.

Barad, K. (1996). "Meeting the Universe Halfway: Realism and Social Constructivism Without Contradiction." In Lynn H. Nelson and Jack Nelson, eds. Feminism, Science and the Philosophy of Science, 161-194. Dordrecht: Kluwer

Barad K. (1998). "Getting Real: Technoscientific Practices and the Materialization of Reality." differences 10: $87-128$

Barad, K. (2003). "Posthumanist Performativity: Toward an Understanding of how Matter Comes to Matter." SIGNS: Journal of Women in Culture and Society 28(3): 801-831.

Bennett, J. (2001). The Enchantment of Modern Life: Attachments, Crossings, and Ethics. Princeton: Princeton University Press.

Bennett, Jane (2010). Vibrant Matter: A Political Ecology of Things (Durham, N.C.: Duke University Press.

Margaret Cavendish, Philosophical Letters, or, Modest reflections upon some opinions in natural philosophy maintained by several famous and learned authors of this age, expressed by way of letters. London: s.n., 1664

Margaret Cavendish, Observations upon Experimental Philosophy. London: A. Maxwell, 1666.

Margaret Cavendish, Grounds of Natural Philosophy (London: A. Maxwell, 1668)

Coole, D., and Frost, S. (2010). "Introducing the New Materialisms." In Coole and Frost (Eds.), New Materialisms: Ontology, Agency, and Politics, 1-43. Durham: Duke University Press.

Davis, N. (2009). "New Materialism and Feminism's Anti-Biologism: A Response to Sara Ahmed." European Journal of Women's Studies 16: 67-80.

Deleuze, G. 1990. Spinoza and the Problem of Expression, trans. M. Joughin. New York: Zone Books.

Dolphijn, R. \& van der Tuin, I. (2012). New Materialism: Interviews \& Cartographies. Ann Arbor: Open Humanities Press (MPublishing, University of Michigan Library).

Engels, F. (1982). Ludwig Feuerbach und der Ausgang der klassischen deutschen Philosophie (1888), in Marx, K., Engels, F. Werke, vol. 21. Dietz Verlag, Berlin.

Frost, S. (2011). "The Implications of the New Materialisms for Feminist Epistemology," in Feminist Epistemology and Philosophy of Science: Power in Knowledge, edited by Heidi E. Grasswick, 69-83. London and New York: Springer.

Gatens, M. (ed.), Feminist Interpretations of Benedict Spinoza. University Park, PA: Penn State University Press, 2009.

Grosz, E. (2011), 'Life, Matter. And Other Variations', Philosophy Today 55: 17-27

Hird, M. (2004) 'Feminist Matters: New Materialist Considerations of Sexual Difference', Feminist Theory 5(2): 223-232.

Husserl, E. (1976). La crise des sciences européennes et la phénoménologie transcendantale; trad. Gérard Granel. Paris : Gallimard.

Kirby, Vicky (1997) Telling Flesh: The Substance of the Corporeal. New York: Routledge. 
Korichi, M. 2000. Defining Spinoza's Possible Materialism. Graduate Faculty Philosophy Journal 22:1, special issue The Renewal of Materialism, 53-69

La Mettrie, J.O. de (1751/1987). Euvres philosophiques, ed. F. Markovits, 2 vols. Paris: Fayard"Corpus".

Merleau-Ponty, M. (1963). The Structure of Behaviour, trans. A.L. Fisher. Boston: Beacon Press.

October 155 (Winter 2016), questionnaire on new materialism, eds. Joselit, D., Lambert-Beatty, C., Foster, H, 3-110.

Riskin, J. (2003). "The Defecating Duck, or, the Ambiguous Origins of Artificial Life." Critical Inquiry 29(4): 599-633

Thompson, E. (2007). Mind in Life: Biology, Phenomenology, and the Sciences of Mind. Cambridge, Mass.: Harvard University Press.

Toland, J. (1704). Letters to Serena. London: B. Lintot.

Tosel, A. (1994). Du matérialisme de Spinoza. Paris: Kimé.

Wolfe, C.T. (2012). "Forms of Materialist Embodiment." In Matthew Landers and Brian Muñoz, (Eds.), Anatomy and the Organization of Knowledge 1500-1850, 129-144. London: Pickering and Chatto.

Wolfe, C.T. (2015). "Diderot and materialist theories of the self." Journal of Society and Politics 9(1): 75-94

Wolfe, C.T. 2016. Materialism. A Historico-Philosophical Introduction, Springer Briefs. Dordrecht: Springer.

Wolfe, C.T. (forthcoming). Varieties of vital materialism, in S. Ellenzweig and J. Zammito, eds., New Materialism and the Politics of Ontology (volume under review). 